\title{
THE ROLE OF ARCHITECTURAL EDUCATION FOR SUSTAINABLE CONSTRUCTION: A CASE STUDY AT UNIVERSITY OF BALIKESIR IN TURKEY
}

\author{
Yeliz TÜLÜBAȘ GÖKUÇ \\ Balıkesir University, Turkey \\ yeliz@balikesir.edu.tr \\ https://orcid.org/0000-0003-3594-7977
}

\begin{abstract}
Today, the concept of sustainability is a very popular topic in the construction sector as in all areas of the industry. When the environmental impacts of the building life cycle are considered, the importance of this concept for this sector is seen more clearly. As in every education field, architectural education is also shaped according to the needs of the age. The differences between 2000s and today can be noticed when looking at the field of architecture that shifts in line with the needs of the age. Thus, necessary changes should be made in some disciplines such as architecture, interior architecture, civil engineering, city and regional planning and landscape architecture under the subject of sustainability. Architecture, which shapes the living spaces, has an enormous responsibility along with some other disciplines during the evolution of the occupational environmental awareness. It should be ensured with the university education that the undergraduate architecture students develop a mentality that pays attention to the concepts of ecology and sustainability, and enables skills to utilize renewable energy sources. This study aims to determine the awareness of students on sustainability. The data for this research is collected by conducting a survey at the Department of Architecture at the University of Balıkesir, and covers the senior students in the spring semester of 2018-2019 and 2019-2020 academic years. This study emphasizes the concept of sustainability, and aims to determine how the architect candidates who will be implementers in the future interact with the concept of sustainability during their higher education. One of the results of the study shows that students do not have much knowledge about sustainable architecture, but they tend to take related courses. Another result of the study is that students should be directed to projects that emphasize sustainability in architectural design courses.
\end{abstract}

Keywords: Sustainability, Architectural Education, Sustainable Construction, Sustainable Buildings.

\section{SÜRDÜRÜLEBİLIR YAPIM ICÇIN MIMARLIK EĞİTIMININ ROLÜ: TÜRKIYYE BALIKESIR ÜNIVERSITTESİ'NDE BİR VAKA ANALIZİ}

\section{ÖZ}

Günümüzde sürdürülebilirlik kavramı, endüstrinin her alanında olduğu gibi inşaat sektöründe de oldukça dikkat çekici bir konudur. Özellikle bina yaşam döngüsünün çevresel etkileri düşünüldüğünde sürdürülebilirlik kavramının inşaat sektörü için önemi daha iyi anlaşılmaktadır. Her eğitim alanında olduğu gibi mimarlık eğitimi de çağın gereksinimlerine göre şekillenmektedir. Çağın ihtiyaçları doğrultusunda değişen mimarlık alanına bakıldığı zaman yirmi yıl öncesi ile günümüzde bazı farklılıklar bulunmaktadır. Sürdürülebilirlik konusunda mimarlık, iç mimarlık, inşaat mühendisliği, şehir ve bölge planlaması ve peyzaj mimarlığı gibi disiplinlerin eğitim aşamalarında bazı değişikliklere gidilmesi gerekmektedir. Mesleki çevre duyarlılığının gelişim sürecinde, yaşam alanlarını biçimlendiren mimarlığa diğer disiplinlerle birlikte büyük sorumluluk düşmektedir. Mimarlık öğrencisinin özellikle lisans düzeyinde alacağı eğitimle ekoloji ve sürdürülebilirlik kavramlarını önemseyen, yenilebilir enerji kaynaklarını kullanabilen bir birikim oluşturması 
sağlanmalıdır. Bu çalışma; Balıkesir Üniversitesi Mimarlık bölümü lisans 4. sınıf öğrencilerinin sürdürülebilirlik konusundaki farkındalıklarını belirlemeyi amaçlamaktadır ve çalışma için gerekli olan veriler bir anket çalışması yapılarak toplanmıştır. Anket çalışması; 2018-2019 ve 2019-2020 eğitim öğretim yılları bahar döneminde 4. sınıf öğrencilerine uygulanmıştır. Sürdürülebilirlik kavramına dikkat çekmeye çalışan bu çalışma, bina ölçeğinde uygulayıcı olacak mimar adaylarının, eğitim sürecinde sürdürülebilirlik kavramı ile ne kadar etkileşimde olduklarını belirlemeyi amaçlamaktadır. Çalışmanın sonuçları; öğrencilerin sürdürülebilir mimarlık konusunda çok fazla bilgi sahibi olmadıklarını ancak bu dersleri almaya istekli olduklarını göstermektedir. Çalışmanın bir diğer sonucu da öğrencilerin mimari tasarım derslerinde sürdürülebilirlik konusuna vurgu yapan projelere daha çok yönlendirilmesi gerekliliğidir.

Anahtar Kelimeler: Sürdürülebilirlik, Mimarlık Eğitimi, Sürdürülebilir Yapım, Sürdürülebilir Binalar.

\section{INTRODUCTION}

The unconscious consumption of energy resources and emerging environmental problems are among the most important problems of the century that we face. The environmental and energy problems faced in the second half of the 20th century have led countries to find new energy sources, also to make use of the existing energy resources effectively has been included in the energy policies of many countries. Sustainability, which aims to conserve the nature and resources, has been accepted at the community level in many countries, and this concept has allowed the reevaluation of the buildings that have the most important share in energy consumption. A great energy is used from raw material extraction to construction, application and demolition phases in the construction sector that causes environmental pollution through the excessive use of natural resources (Topak et al.,2019). According to a study conducted in the USA, buildings in the traditional construction sector consume about $12 \%$ of water resources, $30 \%$ of raw material obtained from nature, and $39 \%$ of global energy resources during construction and operation. The construction sector is responsible for $30 \%$ of the waste generated both during construction and after completing the building life cycle (Stelmack et al.,2014). On the other hand, approximately $40 \%$ of the carbon dioxide $\left(\mathrm{CO}_{2}\right)$ emission which is the primary cause of global warming, originates from the construction sector (Cottrell,2012; US Department of Energy,2008). For this reason, sustainable design concept is especially important in this sector. For the solution of these problems and a sustainable future, it is necessary to design sustainable buildings with an innovative approach that will eliminate the negative impacts on environment and human health. These buildings consume less water and energy than the traditional ones, and have less environmental impact. Systems that increase energy efficiency used in sustainable buildings not only reduce the environmental impact of buildings, but also affect construction costs.

One of the biggest actors of energy consumers in the world is the construction sector, and the architectural discipline plays an active role in the solutions to the environmental problems that arise in this context. The construction site and the construction process at the beginning have a negative impact on local ecological features of the environment. Also, the production methods of the materials used in the buildings affect the global environment adversely. The buildings have a long-term interaction with the environment after they are built. For these reasons, today's and future architects are responsible for designing and creating sustainable environments. So, architectural education is an important approach that can provide a sense of environmental responsibility and contribute to sustainability education. Some research on sustainability education have carried out in architectural discipline. It is observed that some remarkable architecture schools around the world have adapted sustainability to their undergraduate curriculum (Boarin et al.,2020; Iulo et al.,2013). Unfortunately, many architecture schools in Turkey especially in developing universities cannot perform the same success. The most important reasons are the low number of faculty members who trained in this field, and the faculty members who specialized on this field are not able to devote enough time to such courses due to their excessive course loads. In this paper, the current curriculum of the Architecture Department of the University of Balikesir (BAUN) was examined within the scope of sustainability and ecology courses. Afterwards a comparison was made with the top five architecture departments of public universities in Turkey which accept students with the highest score according to the Higher

Submit Date: 25.09.2020, Acceptance Date: 27.10.2020, DOI NO: 10.7456/11101100/018

Research Article - This article was checked by iThenticate

Copyright $($ ) The Turkish Online Journal of Design, Art and Communication 
Education Council. In the second part of the study, a survey was conducted in order to determine the awareness of the senior students of architecture department on sustainability.

\section{SUSTAINABILITY AND SUSTAINABLE DEVELOPMENT}

The concept of sustainability was first discussed under the name of 'Environmental Protection and Development' at the United Nations Stockholm Conference, which was held in 1972 with the participation of 113 countries worldwide. Important steps were taken during this conference especially in establishing sustainability awareness (United Nations,1972). The main purpose of the sustainability approach is to control the environmental degradation process and to reorganize human actions by defining the necessary measures. According to the definition made by the World Environment and Development Commission in 1987, sustainability is the ability to meet today's needs without compromising the ability of future generations to meet their own needs (UN WCED,1987). The concept of sustainable development has found wide acceptance by the World Environment and Development Commission's 1987 report titled 'Our Common Future'. The definition of sustainable development is defined in this report as "Sustainable development is development that meets the needs of the present without compromising the ability of future generations to meet their own needs." (UN WCED,1987). Along with these developments, the concept of sustainability has become a research area not only for the disciplines of science such as environment and ecology, but also many fields that are indexed to production and consumption. Various design methods have been developed to become part of solutions to environmental problems, especially during the building design, application and utilization phases. This concept emerged with the studies of environmental research in the field of design in 1970s. Since then it has reached a holistic approach with cultural and social research. Buildings are responsible for approximately $40 \%$ of the $\mathrm{CO}_{2}$ emissions in the world (Somal1 and Ilical1,2009). In order to reduce carbon emissions and their rapidly progressing negative effects, various assessment systems for environmental problems have been established in many countries around the world, and several certificates have been issued to the buildings that meet specified criteria. BREEAM (UK), LEED (USA), CASBEE (Japan) and SBTOLL (International) are some of the certification systems. Chang et al. (2015) emphasized that the relationship between sustainability and competitiveness may be an important factor for companies (Chang et al.,2015), while another study (Zhang et al., 2011) stated that the use of green technologies can contribute to the companies' reputation. The results of the study of de Paula et al. (2017) show that $89 \%$ of the contracting companies participating in the survey tend to recruit staff who has some knowledge about sustainability (de Paula et al.,2017).

\section{ARCHITECTURAL EDUCATION FOR SUSTAINABLE CONSTRUCTION}

The techniques for sustainability that aims to reduce the environmental impacts of buildings are discussed within the framework of materials, construction technologies and energy-based design approaches in the construction sector. In the light of scientific studies, it is aimed to determine the goals and strategies regarding sustainable building design. Most of the world's natural resource usage is realized by construction sector, and it is known that buildings cause most of the environmental problems related to the extreme use of energy and resource. In this context, sustainable building design is important in terms of minimizing the environmental problems caused by the buildings as well as limiting the resource use (Karaca and Çetintaş,2015).

Mclennan (2004) defined sustainable design in his book called 'Sustainable Design Philosophy' as " $a$ design philosophy that seeks to maximize the quality of the built environment, while minimizing or eliminating negative impact to the natural environment". Kim and Rigdon (1998) developed a conceptual framework to ensure the sustainability in architecture, and this framework consists of three main principles: Life Cycle Design, Economy of Resources, and Humane Design. The Life Cycle Design principle recognizes to analyze the environmental impact of construction processes in all phases during a building's existence (Kim and Rigdon,1998). The Economy of Resources principle is concerned with the reduction, reuse and recycling of natural resources. The last principle which is the 
Humane Design principle is concerned with the interactions between humans and the nature, such as land planning and design for human comfort.

In the construction sector, discussions are held on how environmental impacts of buildings can be reduced with an understanding of sustainability in terms of materials, construction technologies and energy-based design approaches. Sustainability is one of the major areas in architectural discipline and it is important to adapt it to the architectural curriculum. The Architectural Design Studio is one of the courses with the highest ECTS credits in architectural education. Design Studio is modeled around problem solving practices, and should be considered as a unique learning environment. Related studies in the literature are summarized in the following paragraphs.

The study of Enshassi and Mayer (2005) focused on the obstacles to sustainable implementations in the construction sector in Palestine. It was observed that stakeholders' lack of knowledge in the construction process was one of the serious obstacles. Also, authors claim in this study that the curricula that helps to train manpower for the sector should be revised.

Shari and Jaafar (2006) conducted a survey with 67 architectural educators from nine architecture schools in Malaysia. According to the results of this study, awareness of sustainability should be raised with continuous and systematic education programs organized by both government and universities. In addition, the importance of addressing sustainability issues in architectural design courses was emphasized.

According to Taleghani et al. (2011), today renewable energy education has a unique identity within the architectural discipline. However, traditional architectural curriculum does not include renewable energy resources subjects. In this study, Iran and Australia were compared, and the results of this study emphasized the lack of experts in this field. It was also emphasized that opportunities for continuing vocational education should be provided in these areas, and awareness of professionals should be raised through graduate and doctorate courses.

Yüksek (2013) examined the course contents in the architecture departments of universities in Turkey, and the intention of this study was to determine the extent to which they give place to the sustainability issues. The results of the study show that the courses about 'sustainable architecture' in the curricula of the architecture departments of universities have increased, but this improvement is not sufficient.

Allu (2014) conducted a survey at the University of Jos-Nigeria covering lecturers of architecture department, senior students and graduate students. University of Jos is one of the leading institutions providing architecture education in Nigeria. The study concluded that education has a significant impact on the future roles of architects and their sustainable implementation skills.

According to Arat and Uysal (2016), architecture is one of the most critical fields for construction operations, recycling, sustainability and efficient use of energy resources. In this study, the evaluation and comparison of the courses within the scope of sustainability and ecology were made in the architecture departments of private and public universities in Turkey and Turkish Republic of Northern Cyprus between the years of 2010 to 2015. As a result of these evaluations, it was determined that the courses about ecology and sustainability were not sufficient in the curricula of 2010, but the number of these courses increased relatively in 2015.

The study of El-Feki and Kenawy (2018) focuses on how sustainability can be integrated into the curricula of architecture departments in some Egyptian universities. Within the scope of this study, interviews were made with lecturers and senior students. All participants agree that the concepts of sustainability should be integrated with the architectural curriculum, also should be monitored and 
updated constantly. In the study, despite the efforts shown in Egypt (such as the generation of GPRSGreen Pyramid Evaluation System), it was concluded that this was still not sufficient.

In the first stage of this study, the undergraduate curricula of the top five architecture departments of public universities in Turkey which accepted students with the highest score of the year 2019 according to the Higher Education Council, and the architecture department of BAUN's curriculum were examined. As can be seen in Table 1 below, the ECTS credits of the compulsory and elective courses related to sustainability are given by universities. The information in the table is collected from the web pages of the architecture departments.

Table 1. ECTS credits of Compulsory and Elective Courses in the Department of Architecture in Turkey

\begin{tabular}{|c|c|c|c|c|c|}
\hline Universities & 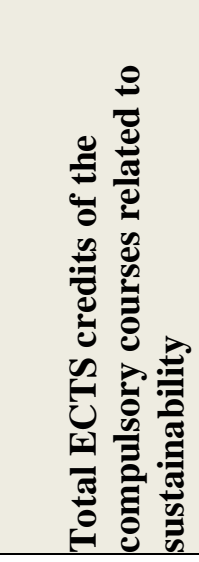 & 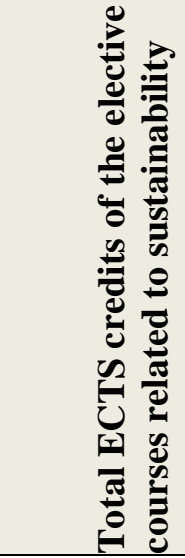 & 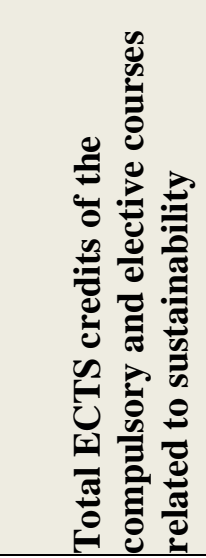 & 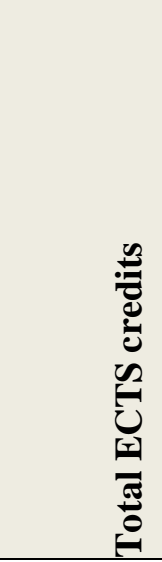 & 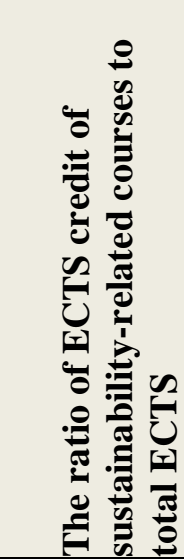 \\
\hline $\begin{array}{l}\text { Istanbul } \\
\text { Technical } \\
\text { University } \\
\text { (ITU) }\end{array}$ & 6 & 44 & 50 & 240 & $20.8 \%$ \\
\hline $\begin{array}{l}\text { Middle East } \\
\text { Technical } \\
\text { University } \\
\text { (METU) }\end{array}$ & 12 & 16 & 28 & 240 & $11.6 \%$ \\
\hline $\begin{array}{l}\text { Yildiz } \\
\text { Technical } \\
\text { University } \\
\text { (YTU) }\end{array}$ & 6 & 32 & 38 & 240 & $15.8 \%$ \\
\hline $\begin{array}{l}\text { Gazi } \\
\text { University }\end{array}$ & 12 & 3 & 15 & 240 & $6.25 \%$ \\
\hline $\begin{array}{l}\text { Mimar Sinan } \\
\text { Fine Arts } \\
\text { University } \\
\text { (MSGSU) }\end{array}$ & 4 & 30 & 34 & 240 & $14.1 \%$ \\
\hline $\begin{array}{l}\text { Balikesir } \\
\text { University } \\
\text { (BAUN) }\end{array}$ & 5 & 16 & 21 & 240 & $8.75 \%$ \\
\hline
\end{tabular}

In the bachelor of Architecture curriculum of BAUN, there are four elective courses (Heat and Humidity Control, Introduction to Climate Conscious Architecture, Ecological Change and Sustainable Architecture, and Energy Efficient Building Design) and one compulsory course (Building Physics). Undergraduate students encounter these courses in the fifth semester (Introduction to Climate Conscious Architecture, Ecological Change and Sustainable Architecture). Building Physics 
course, which is a compulsory subject, takes place in the sixth semester, and in the seventh semester, there are elective courses called Heat and Humidity Control and Energy Efficient Building Design. Students determine elective courses based on their interests. As a rule, students are allowed to enroll for elective courses within the quota, and when the quota is full, students are directed to other elective courses. Apart from the compulsory course (Building Physics), there are also students who graduate without ever taking elective courses.

\section{RESEARCH METHOD}

The data required for this study, which aims to determine the sustainability awareness of the senior students of BAUN, was collected by conducting a survey called 'Sustainability in Architectural Education'. Survey questions are prepared in SurveyMonkey application.

\section{Organization of the Survey}

The survey consists of six questions; five of them are categorical and one of them is Likert type. The first question of the survey is to determine the gender of the students. The second question is aimed at measuring how competent do the students consider themselves in sustainability. In the third and fourth questions of the survey, students are asked which green building certification systems and building energy performance assessment tools do they know about. The fifth question of the survey is of Likert type and consists of some statements about sustainability. The students were asked to specify their level of agreement to some statements in five-point Likert scale, it was graded as (1) Strongly disagree; (2) Disagree; (3) Neither agree nor disagree; (4) Agree; (5) Strongly agree. The last question of the survey concerns if the students consider sustainability issues in their projects within the scope of architectural design courses. The study includes the senior year students studying at BAUN, Department of Architecture in the 2018-2019 and 2019-2020 academic years. 47 students were contacted via e-mail, while 70 students were interviewed face-to-face. In total, the survey was evaluated with responses from 107 individual participant.

\section{FINDINGS}

$53.27 \%$ of the survey participants are male, while the rest of the participants are female as shown in Figure 1.

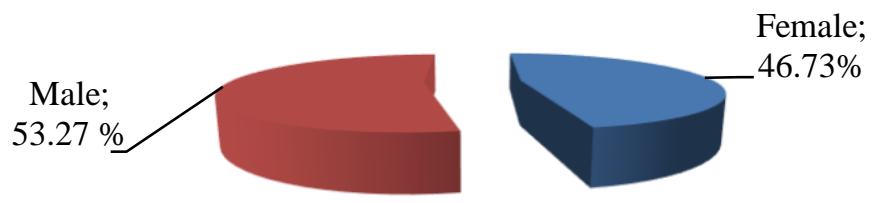

Figure 1. Gender of the Participants

The participants were asked whether they have enough knowledge about sustainable architecture. While $76.64 \%$ of the respondents said no, the rest of the answers were collected to be yes.

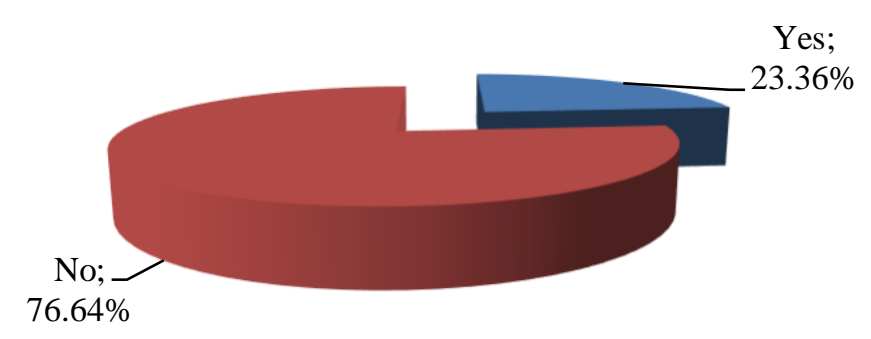

Figure 2. "Do you think you have enough knowledge about sustainable architecture?" 
In the third question of the survey, students were asked which of the green building certification systems they were aware. As can be seen from Table 2 below, $49.53 \%$ of the participants were aware of LEED.

Table 2. "Which of the following green building certification systems are you aware of?"

\begin{tabular}{|l|l|l|}
\hline Answer Choices & Responses & \\
\hline LEED & $49.53 \%$ & 53 \\
\hline Green Star & $31.78 \%$ & 34 \\
\hline None & $29.91 \%$ & 32 \\
\hline Green Globes & $28.04 \%$ & 30 \\
\hline BREEAM & $17.76 \%$ & 19 \\
\hline CASBEE & $7.48 \%$ & 8 \\
\hline DGNB & $6.54 \%$ & 7 \\
\hline HQE & $5.61 \%$ & 6 \\
\hline Other (Please specify) & $1.87 \%$ & 2 \\
\hline & Total Respondents: 107 \\
\hline
\end{tabular}

In the fourth question of the questionnaire, students were asked which building energy performance assessment tools they are aware of. The answers given to this question are given in Table 3.

Table 3. "Which of these building energy performance assessment tools are you aware of?"

\begin{tabular}{|l|l|l|}
\hline Answer Choices & Responses & \\
\hline Energy-Plus & $44.86 \%$ & 48 \\
\hline EcoDesigner & $38.32 \%$ & 41 \\
\hline Green Building Studio & $29.91 \%$ & 32 \\
\hline Ecotect & $28.97 \%$ & 31 \\
\hline None & $27.10 \%$ & 29 \\
\hline Energy-10 & $24.30 \%$ & 26 \\
\hline Virtual Environment VE-Pro & $11.21 \%$ & 12 \\
\hline e-QUEST & $4.67 \%$ & 5 \\
\hline Esp-r & $1.87 \%$ & 2 \\
\hline TRNSYS & $1.87 \%$ & 2 \\
\hline & Total Respondents: 107 \\
\hline
\end{tabular}

The fifth question of the survey is of Likert type and consists of some statements about sustainability. The responses given to these statements are given in Table 4.

Table 4. Assessment items about sustainability

\begin{tabular}{|l|l|}
\hline Assessment Items & Mean scores \\
\hline I am willing to take courses about sustainability. & 3.98 \\
\hline $\begin{array}{l}\text { It might be easier to find a job if I have sufficient knowledge/experience in } \\
\text { sustainable architecture. }\end{array}$ & 3.79 \\
\hline $\begin{array}{l}\text { It might be easier to find a job if architectural projects related to } \\
\text { sustainability are in my portfolio. }\end{array}$ & 3.62 \\
\hline $\begin{array}{l}\text { I have studied on projects emphasizing sustainability, as part of our } \\
\text { architectural design courses. }\end{array}$ & 3.13 \\
\hline Some of our architectural design courses emphasize sustainability. & 2.96 \\
\hline I have enrolled a sufficient number of elective courses on sustainability. & 2.50 \\
\hline I have enrolled a sufficient number of compulsory courses on sustainability. & 2.30 \\
\hline I believe there are enough courses on sustainability in our curriculum. & 2.27 \\
\hline
\end{tabular}

The students were asked what they did in their projects related to sustainability issues in architectural design courses. Responses to this question are shown in Table 5. 
Table 5. Sustainability issues used in the projects

\begin{tabular}{|l|l|}
\hline $\begin{array}{l}\text { Which of the following have you considered in your projects regarding } \\
\text { sustainability within the scope of your architectural design courses? }\end{array}$ & Answers \\
\hline Natural lighting & $85.05 \%$ \\
\hline Natural ventilation & $80.37 \%$ \\
\hline The use of green roof & $74.77 \%$ \\
\hline Selection of the appropriate building form & $53.27 \%$ \\
\hline $\begin{array}{l}\text { Selection of sustainable building materials (use of recyclable materials, use of } \\
\text { local and regional building materials, materials requiring less energy during the } \\
\text { production phase) }\end{array}$ & $45.79 \%$ \\
\hline Use of photovoltaic panels & \\
\hline Compliance with topography & $44.86 \%$ \\
\hline Rainwater collection, accumulation and reuse & $42.99 \%$ \\
\hline Use of plants inside and outside the building to contribute to space comfort & $42.06 \%$ \\
\hline Using energy glasses & $41.12 \%$ \\
\hline Preserving the existing flora and fauna in the project area & $38.32 \%$ \\
\hline Solar collectors (for hot water) & $34.58 \%$ \\
\hline Insulation in building envelope & $26.17 \%$ \\
\hline Gray water treatment and reuse & $23.36 \%$ \\
\hline Passive Solar Heating & $22.43 \%$ \\
\hline Heat pump usage & $21.50 \%$ \\
\hline Utilization of the warming/cooling effect of soil & $9.35 \%$ \\
\hline Waste heat recovery & $5.61 \%$ \\
\hline Biomass effect & $5.61 \%$ \\
\hline Thermal mass effect & $4.67 \%$ \\
\hline Contributing to sustainability by integrating nanotechnology into architecture & $4.67 \%$ \\
\hline None of the above & $3.74 \%$ \\
\hline & $0.93 \%$ \\
\hline
\end{tabular}

\section{DISCUSSION}

$76.4 \%$ of the students think that they do not have any knowledge about sustainable architecture. The insufficient level of awareness regarding sustainable architecture is worrying considering that future architects are one of the stakeholders in the construction sector. AlSanad (2015) conducted a survey with the stakeholders in construction sector in Kuwait. According to the results of this study, the level of sustainability awareness of stakeholders is ranged from medium to low. To ensure sustainability and build environmentally friendly buildings, it is unavoidable to increase the awareness of stakeholders in the sector, and education is one of the most important factors at this point. There are other studies (Shafii et al., 2006; Serpell et al.,2013) in the literature that publicize the inadequate knowledge of the stakeholders in the sector regarding sustainability.

It is disappointing that the senior students, who are about to graduate, are not aware of programs such as LEED (49.53\%) and BREEAM (17.76\%). The LEED system which is developed and used by the United States Green Building Council (USGBC) in the USA, is a green building certification system used extensively in construction projects all over the world (Gürgün,2017). This system which also often preferred in Turkey, encourages the use of sustainable practices in construction projects, including energy efficiency. This system is scored on different credit categories and buildings are entitled to receive certificates at different levels according to the points earned. BREEAM, another green building certification system is the first green building evaluation system developed in the UK in 1990. Therefore, it is recognized as the most trusted certification system today (Urük and Külünkoğlu,2019). The survey results of Chen et al. (2008) showed similarities with this study. Less than $10 \%$ of senior architecture students participating in the survey are aware of the BREEAM program. 
Sustainability awareness is important not only for architects but also its users. It is known that a large part of society including stakeholders do not have enough knowledge about sustainability and sustainable construction (Koman and Eren,2006). Similar results were found in the survey conducted by Koman and Eren (2006). The participants think that both architects and contractors have a lack of training on sustainability, and even they state that they are not interested in this issue. The ratio of participants who have knowledge about the concept of sustainability, sustainable architecture, and sustainable construction is $25 \%$, which is extremely low considering the high education levels of the participants. The development and become widespread of environmental awareness and sustainability concepts are directly dependent on interest groups and power elites such as trade, industry and politics. In developing countries such as Turkey, the expansion of sustainable construction concept does not depend on just interest groups and power elites, also depends on informing and raising awareness of every segment of the society (Tercan,2000). Developing countries have to find new approaches without sacrificing the gains of the modern age. The most crucial phase of this attempt in architecture is the reevaluation of the relationship between design and technology. It is significant to raise the awareness of the society especially on the use of local and recycled materials (Koman and Eren,2006).

It is extremely important to adapt the concept of sustainability to the architectural curriculum, and one of the ways is to focus on sustainability issues in architectural design courses. Students mostly paid attention to natural lighting (85.05\%), natural ventilation $(80.37 \%)$, green roof usage $(74.77 \%)$, and selection of proper building form (53.27\%) in their projects. The fact that the courses related to sustainability at the Architecture Department in BAUN started in the 3rd grade shows that students do not have much opportunity to use their knowledge gained through these courses in architectural design studios or projects. This is equivalent to trying to make an existing building sustainable later, rather than designing a new building with environmental awareness for the first time. This research shows that students cannot enroll enough courses related to sustainable construction in the current curriculum, but they are willing to take these courses. Students are enrolled to the elective courses within a certain quota. Elective courses can be enrolled within a certain quota that causes some students cannot enroll for the elective courses they want. It is important to highlight that students can graduate without taking any elective courses related to sustainability, and therefore the number of compulsory courses related to this subject should be increased. For a more qualified architectural education that integrates the concept of sustainability into architectural design studios and the entire curriculum, architectural departments and all other relevant disciplines should review and perhaps reconstruct their curricula within this framework. As a result of the findings in this research, this paper suggests that the number of compulsory courses given at the Architecture Department of BAUN should be at least two, and the number of proposed elective courses should be increased and diversified.

\section{CONCLUSION}

The aims of architectural education are to prepare the architecture students for the profession, and help them to gain ecological awareness and social responsibilities. In this respect, it should be ensured that architecture students create an accumulation of knowledge that cares about the concepts of ecology and sustainability during their education.

With the adoption of sustainable design approaches in the construction sector, it will be possible to transfer a healthy environment and natural resources to the future generations. The way to maintain the living conditions in the natural balance for us and future generations is to protect the current situation and increase the level of environmental awareness. The construction sector should also lead other disciplines which consume a significant portion of the world's natural resources. Courses covering environmental problems in global and local sense, and fundamental sustainable construction knowledge should be included in the curriculum as compulsory courses of the early stages of architectural education in Turkey. The gained theoretical knowledge should be put into practice with architectural design studio courses and projects. It has been observed that the existence of the courses 
related to sustainability in the curriculum depends on the specialization of the academic staff in these subjects. It can be said that the courses related to these subjects take place more often in the curriculum of the architecture departments of developed and well-established universities like ITU, METU, and YTU. It is vital for developing universities to include these subjects in their curricula.

The concept of sustainability has been found to be partially effective in material, health and comfort issues in architectural design courses which is accepted as the core course of architectural education. In addition, energy, waste management and pollution issues should be addressed within the scope of these courses. However, it should not be forgotten that the curriculum alone is not sufficient, the perception and commitment of both faculty members and students to these subjects are equally important in terms of environmental awareness. Students should be orientated to these fields not only in undergraduate but also in graduate programs. Consequently, making the concept of sustainability as part of architectural education is essential in terms of passing on to future generations more livable environment. For this reason, the curricula should be revised and updated, so that architect candidates perceive sustainability in space designs as one of the space requirements.

\section{REFERENCES}

Allu E.L.A. (2014). Sustainability and architectural education in the University of Jos- Nigeria. Conference of the International Journal of Arts \& Sciences, 07(02):99-106.

AlSanad S. (2015). Awareness, drivers, actions, and barriers of sustainable construction in Kuwait. Procedia Engineering, 118, 969- 983.

Arat Y., Uysal M. (2016). Ekoloji ve sürdürebilirlik kavramlarına ilişkin dersler açısından mimarlık eğitim programlarının irdelenmesi. Online Journal of Art and Design 4(2), 12-34.

Boarin P., Martinez-Molina A., Juan-Ferruses I. (2020). Understanding students' perception of sustainability in architecture education: A comparison among universities in three different continents. J. Clean. Prod. 248.

Chang R, Zillante G, Zhao Z, Zuo J.(2015). Research on sustainability and construction firms: current status and future agenda. Proceedings, International Conference on Construction and Real Estate Management, Luleå, August, 310-317.

Chen B., Pitts A., Ward I. (2008). Sustainability related educational programmes for sustainable housing design. 25th Conference on Passive and Low Energy Architecture, Dublin, Ireland.

Cottrell M., Guide to the LEED AP, Interior Design and Construction (ID+C) Exam. John Wiley \& Sons Inc, Canada, 2012.

de Paula N., Arditi D., Melhado S. (2017) Managing sustainability efforts in building design, construction, consulting, and facility management firms. Eng. Construct. Architect. Manag., 24 (6), 1040-1050.

El-Feki S., Kenawy I. (2018). Integrating sustainability within architectural education in Cairo. International Journal on: Proceedings of Science and Technology, 1-9.

Enshassi A., Mayer E. (2005). Barriers to the application of sustainable construction concepts in Palestine. In Proceedings of the 2005 World Sustainable Building Conference, 27-29 September, Tokyo, Japan.

Gürgün A. (2017) Türkiye'deki LEED NC 2009 sertifikalı binaların enerji ve atmosfer kredilerinin değerlendirilmesi. Politeknik Dergisi, 20(2), 383-392.

Iulo L.D., Gorby C., Poerschke U., Kalisperis L.N., Woollen M. (2013). Environmentally conscious design- educating future architects. International Journal of Sustainability in Higher Education, 14(4), 434-448. 
Karaca Ü.B., Cetintas K.F. (2015). Examination of sustainable building design from the point of legislation view in Turkey and in the World. 2nd International Sustainable Buildings Symposium, 28 30th May, Ankara, Turkey.

Kim, J.J., Rigdon, B. (1998). Sustainable Architecture Module: Introduction to Sustainable Design. National Pollution Prevention Center for Higher Education, The University of Michigan, Michigan.

Koman İ., Eren Ö. (2006). Alternatif sürdürülebilir konut uygulamaları ve Türkiye'deki betonarme konut sektörü. Mimarlık,329, Mayıs-Haziran.

McLennan J.F. (2004). The Philosophy of Sustainable Design: The Future of Architecture. Ecotone LLC, Kansas City,

Serpell A., Kort J., Vera S. (2013). Awareness, actions, drivers and barriers of sustainable construction in Chile. Technological and Economic Development of Economy 19(2): 272-288.

Shafii F., Ali Z.A., Othman M.Z. (2006). Achieving sustainable construction in the developing countries of Southeast Asia. In Proceedings of the 6th Asia-Pacific Structural Engineering and Construction Conference, 5-6 September, Kuala Lumpur, Malaysia.

Shari Z., Jaafar F.Z. (2006). Integration and implementation of sustainability in Malaysian architectural education. In the 40th Annual Conference of the Architectural Science Association ANZAScA, 22-24 November, Adelaide, Australia.

Somalı B., Ilıcalı, E. (2009). Leed ve Breeam uluslararası yeşil bina değerlendirme sistemlerinin değerlendirilmesi. IX. Ulusal Tesisat Mühendisliği Kongresi, 1081-1088, 6-9 Mayıs, İzmir, Türkiye.

Stelmack A.K., Foster K., Hindman D. (2014). Sustainable Residentail Interiors. John Wiley \& Sons.,Canada

Taleghani M., Ansari HR, Jennings P. (2011). Sustainability in architectural education: a comparison of Iran and Australia. Renewable Energy, 36(7), 2021-2025.

Tercan A. Scrutiny of the energy efficiency notion, in terms of connections between design and technology in architecture, Phd thesis, Mimar Sinan Fine Arts University,2000.

Topak F. , Tokdemir O.B. , Pekeriçli M.K. and Tanyer A.M. (2019). Sustainable construction in Turkish higher education context. Journal of Construction Engineering, Management \& Innovation 2(1), 40-47.

United Nations. (1972). Report of the United Nations conference on the human environment. Sockholm, Sweden: United Nations.

UN WCED, W. C. (1987). Report of the world commission on environment and development: our common future. UN World Commission on Environment and Development.

Urük Z.F., Külünkoğlu İ.A.K. (2019). Breeam, Leed ve DGNB yeşil bina sertifikasyon sistemlerinin standart bir konutta karşılaştırılması. Avrupa Bilim ve Teknoloji Dergisi , (15) , 143-154.

US Department of Energy (2008). Building Energy Data Book, Section 1.1.1

Yüksek İ. (2013). The evaluation of architectural education in the scope of sustainable architecture. Proced. Soc. Behav. Sci., 89,496-508.

Zhang X., Shen L., Wu Y. (2011). Green strategy for gaining competitive advantage in housing development: a China study. Journal of Cleaner Production, 19(2),157-167. 